\title{
Pola Pertambahan Berat Badan Bayi Berdasarkan Status Menyusui Eksklusif dan Non-Eksklusif
}

\section{Weight Gain Pattern of Exclusively and Non-Exclusively Breastfed Infants}

\author{
Indah Purnama Sari ${ }^{1 *}$, Yustini Ardillah ${ }^{2}$, Indah Permatasari ${ }^{3}$ \\ ${ }^{1}$ Program Studi Gizi Fakultas Kesehatan Masyarakat, Universitas Sriwijaya \\ ${ }^{2}$ Program Studi Ilmu Kesehatan Masyarakat Fakultas Kesehatan Masyarakat, \\ Universitas Sriwijaya \\ ${ }^{3}$ Program Studi Ilmu Keperawatan Fakultas Kedokteran, Universitas Sriwijaya \\ (*indah_purnamasari@fkm.unsri.ac.id)
}

\begin{abstract}
ABSTRAK
Air Susu Ibu (ASI) eksklusif merupakan salah satu makanan yang sangat penting bagi bayi guna mendukung proses pertumbuhan dan perkembangan yang optimal selama 6 bulan pertama. Namun, kurang dari 70\% bayi yang mendapatkan ASI eksklusif di Kota Palembang. Penelitian ini bertujuan untuk menilai pola pertambahan berat badan pada bayi yang menyusui eksklusif dan non-eksklusif. cross sectional design digunakan dalam penelitian ini. Sampel penelitian ini adalah ibu yang mempunyai bayi yang berusia 7-12 bulan di Kecamatan Seberang Ulu I Kota Palembang. Kriteria inklusi sampel adalah anak terakhir/anak pertama, memiliki berat lahir lebih dari 2500 gram, ibu bersedia menjadi responden dan bayi dengan kelahiran kembar dan prematur menjadi kriteria eksklusi. Teknik pengambilan sampel menggunakan Proportionate Stratified Random Sampling. Independent T-Test menunjukkan bahwa ada perbedaan rata-rata pertambahan berat badan pada bayi yang menyusui eksklusif dibandingkan non-eksklusif (Mean Difference: 433,63 gram; 95\%CI: 27,8 - 839,4 gram). Kesimpulan dalam penelitian ini adalah bayi yang menyusui eksklusif memiliki rata-rata pertambahan berat badan yang lebih tinggi dibandingkan bayi yang menyusui non-eksklusif. Oleh karena itu, dibutuhkan dukungan dari suami dalam memberikan motivasi bagi ibu untuk dapat menyusui eksklusif sampai 6 bulan.
\end{abstract}

Kata kunci : ASI eksklusif, ASI non-eksklusif, berat badan

ABSTRACT

Exclusive breastfeeding is one of the foods that is very important for babies to support the optimal process of growth and development during the first 6 months. However, less than $70 \%$ of babies who get exclusive breastfeeding in Palembang. The study aimed to assess the pattern of infants weight gain among exclusive and nonexclusive breastfed babies. Cross sectional design was used in this study. Samples were mother's who have babies aged 7-12 months in Seberang Ulu I Subdistrict, Palembang. Inclusion criteria were the last child/first child, birth weight more than 2500 grams and mothers willing to be a respondent and babies with multiple births being exclusion criteria. The sampling technique used Proportionate Stratified Random Sampling. Independent T-Test showed that there was mean difference of weight gain in exclusively breastfed infants and non-exclusively breastfed infatns (Mean Difference: 433,63 gram; 95\% CI: 27,8 to 839,4 grams). Conclusion was that exclusively breastfed infants had higher average weight gain than non-exclusively breastfed infants. Therefore, husband's supportwas needed to providing motivation for mothers to exclusively breastfed until 6 months later.

Keywords : Exclusive breastfeeding, non-exclusive breastfeeding, weight 


\section{PENDAHULUAN}

Air Susu Ibu (ASI) adalah makanan sempurna yang tidak hanya mengandung sel darah putih dan protein namun mengandung juga zat kekebalan yang dapat melindungi bayi dari berbagai penyakit infeksi sehingga pertumbuhan dan perkembangan bayi berlangsung secara optimal yang akhirnya dapat menurunkan angka kesakitan dan kematian bayi. Namun, hanya 38\% bayi yang berusia 0-6 bulan di dunia yang mendapatkan ASI eksklusif. ${ }^{1}$ Sementara itu, cakupan pemberian ASI eksklusif pada tahun 2017 di Indonesia hanya sebesar 35,7\% dan belum mencapai target Rencana Strategis Kementerian Kesehatan Tahun 2015-2019 yaitu 44\% ${ }^{2,3}$

Salah satu tindakan atau kegiatan yang termasuk dalam intervensi gizi spesifik dalam 1000 Hari Pertama Kehidupan (HPK) yang merupakan "golden age period" bagi seorang anak yang akan menentukan kualitas kehidupannya pada masa yang akan datang adalah menyusui eksklusif. ${ }^{4}$ Menyusui eksklusif adalah landasan pada kelangsungan hidup dan kesehatan anak karena menyediakan nutrisi penting yang tidak tergantikan dalam mendukung proses pertumbuhan dan perkembangan anak. ${ }^{1}$ Pertumbuhan dan perkembangan merupakan proses yang bersifat continue dan dinamis. Proses pertumbuhan (growth) ditandai dengan adanya perubahan dalam jumlah, besar, ukuran atau bentuk pada tingkat sel, organ maupun individu yang dapat diukur dengan ukuran berat, panjang dan umur tulang. Sedangkan, proses perkembangan (development) ditandai dengan adanya perubahan dalam hal fungsi dan proses pematangan sel maupun organ dan individu seperti perkembangan emosi, intelektual dan tingkah laku. ${ }^{4}$

Beberapa penelitian terdahulu menunjukkan bahwa bayi yang menyusui eksklusif mencapai tingkat pertambahan berat badan yang lebih cepat dibandingkan bayi yang menyusui noneksklusif. Studi Ukegbu \& Uwaegbute tahun 2013 menunjukkan bahwa pada usia 6 bulan, bayi yang menyusui eksklusif $(6,97 \pm 1,05 \mathrm{~kg})$ memiliki ratarata berat badan yang lebih tinggi dibandingkan bayi yang menyusui non-eksklusif $(6,61 \pm 1,92$ $\mathrm{kg}) .{ }^{5}$ Selain itu, studi yang dilakukan Kumar et al, tahun 2017 menyimpulkan bahwa pada usia 4 bulan, bayi yang diberikan ASI eksklusif (7,83 \pm
$1,25 \mathrm{~kg}$ ) memiliki rata-rata berat badan yang lebih tinggi dibandingkan bayi yang diberikan susu formula $(6,88 \pm 1,10 \mathrm{~kg}) .{ }^{6}$ Studi Kupers et al., tahun 2015 menunjukkan bahwa bayi yang menyusui menunjukkan pertambahan berat badan yang lebih pesat pada 1 bulan pertama kehidupan, sedangkan bayi yang mendapatkan makanan selain ASI menunjukkan pertambahan berat badan yang lebih lambat. ${ }^{7}$ Sementara itu, hasil penelitian lain yang sejalan juga menyimpulkan bahwa pada minggu ke-24, rata-rata berat badan bayi yang menyusui eksklusif selama 6 bulan $(6,27 \pm 0,47 \mathrm{~kg})$ lebih tinggi dibandingkan dengan yang tidak menyusui eksklusif $(5,62 \pm 0,47 \mathrm{~kg})(\mathrm{p}=0,003)$ dan terdapat peningkatan berat badan pada bayi yang menyusui eksklusif $(\mathrm{p}<0,001){ }^{8,9}$

Provinsi Sumatera Selatan merupakan salah satu provinsi yang menjadi fokus pemerintah dalam upaya meningkatkan cakupan pemberian ASI eksklusif. Cakupan pemberian ASI eksklusif di Provinsi Sumatera Selatan mengalami penurunan dalam kurun waktu tahun 2013 (74,49\%), tahun $2014(64,5 \%)$, tahun $2015(60,3 \%)$ dan tahun $2016(45,3 \%) .^{2}$ Sedangkan, cakupan pemberian ASI eksklusif di Kota Palembang, ibu kota Provinsi Sumatera Selatan, mengalami fluktuasi dalam kurun waktu tahun 2013 sampai 2016. Cakupan pemberian ASI eksklusif pada tahun 2013 (71,13\%), tahun 2014 (74,18\%), tahun 2015 $(72,91 \%)$ dan tahun $2016(68,60 \%)$. Sementara itu, cakupan pemberian ASI eksklusif di Kecamatan Seberang Ulu I memiliki cakupan program yang lebih rendah dibandingkan cakupan program di Kota Palembang yaitu pada tahun $2013(67,87 \%)$, tahun $2014(72,87 \%)$, tahun $2015(66,89 \%)$ dan tahun $2016(67,82 \%) .{ }^{10}$ Hal ini menunjukkan bahwa tidak semua bayi disusui secara eksklusif selama 6 bulan pertama hidupnya. ASI merupakan makanan utama dan pertama bagi bayi yang mengandung kombinasi dan jumlah gizi yang dibutuhkan bayi secara lengkap dan sempurna guna mencapai keadaan status gizi optimal antara lain pertambahan berat badan. Oleh karena itu, penelitian ini bertujuan untuk menilai pola pertambahan berat badan antara bayi yang menyusui eksklusif dan non-eksklusif serta untuk menganalisis keterkaitan antara karakteristik sosial demografi ibu dengan pemberian ASI eksklusif. Sementara itu, hipotesis dalam penelitian ini adalah 
ada perbedaan rata-rata pertambahan berat badan pada bayi yang menyusui eksklusif dan noneksklusif.

\section{BAHAN DAN METODE}

Penelitian ini menggunakan pendekatan analitik kuantitatif dengan cross sectional design. Penelitian dilaksanakan di Kecamatan Seberang Ulu I Kota Palembang. Populasi target adalah seluruh ibu yang memiliki bayi lahir hidup dan populasi studi adalah seluruh ibu yang memiliki bayi yang berusia $0-12$ bulan di Kota Palembang. Sampel penelitian ini adalah ibu yang memiliki bayi yang berusia $7-12$ bulan yang memenuhi kriteria inklusi (anak terakhir/anak pertama, memiliki berat lahir lebih dari 2500 gram dan ibu bersedia menjadi responden) dan kriteria eksklusi (kelahiran kembar dan prematur). Perhitungan besar sampel menggunakan rumus uji beda 2 ratarata (independen) dan uji beda dua proporsi, sehingga diperoleh sebanyak 222 ibu bayi yang menjadi responden penelitian. Teknik pengambilan sampel menggunakan teknik acak berstrata yang dilakukan secara proporsional (Proportionate Stratified Random Sampling). Kecamatan Seberang Ulu I memiliki 5 puskesmas yang keseluruhannya diambil sebagai sampel dengan jumlah sampel untuk masing-masing puskesmas terdistribusikan secara proporsional dan dalam penentuan sampel bayi terpilih di masing-masing puskesmas dilakukan secara random dengan menggunakan tabel random.

Analisis data dilakukan dengan menggunakan teknik analisis univariat dan bivariat. Analisis univariat dilakukan untuk menjelaskan/ menggambarkan keseluruhan variabel penelitian, sedangkan analisis bivariat dilakukan untuk menguji hubungan antara variabel independen dan variabel dependen. Uji T-Independen dipilih dalam analisis secara bivariat untuk mengetahui perbedaan rata-rata berat badan pada bayi yang menyusui eksklusif dan non-eksklusif serta uji Chi-Square untuk menganalisis keterkaitan antara karakteristik sosial demografi ibu dengan pemberian ASI eksklusif dengan nilai $\mathrm{p} \leq 0,05$ yang signifikan secara statistik. Penyajian data dalam bentuk gambar, tabel dan narasi. Variabel dalam penelitian ini adalah berat badan bayi, pemberian ASI eksklusif, umur ibu melahirkan, pendidikan ibu, pendidikan suami, pekerjaan ibu, paritas, tingkat kesejahteraan keluarga dan tempat bersalin. Data berat badan bayi ditelusuri dengan melihat catatan hasil penimbangan berat badan bayi pada buku Kesehatan Ibu dan Anak (KIA), catatan bidan dan ingatan ibu. Pertambahan berat badan dinilai dengan menselisihkan berat badan pada bulan ke-6 dengan berat badan pada saat lahir. Sedangkan pemberian ASI eksklusif didefinisikan sebagai pemberian hanya ASI saja tanpa tambahan makanan/minuman apapun sesaat setelah bayi dilahirkan sampai bayi berusia 6 bulan, kecuali pemberian obat/ vitamin/ mineral.

\section{HASIL}

Hasil analisis univariabel menunjukkan bahwa sebanyak 79,7\% ibu berumur 20-35 tahun pada saat melahirkan. Ibu berpendidikan tinggi (SMA keatas) lebih banyak 1,8\% dibandingkan ibu berpendidikan rendah (SMP ke bawah) dengan suami berpendidikan tinggi juga lebih banyak

Tabel 1. Karakteristik Responden

\begin{tabular}{|c|c|c|}
\hline Karakteristik & $\mathrm{n}=\mathbf{2 2 2}$ & $\%$ \\
\hline \multicolumn{3}{|c|}{ Umur ibu melahirkan (tahun) } \\
\hline $20-35$ & 177 & 79.7 \\
\hline$<20$ dan $>35$ & 45 & 20.3 \\
\hline \multicolumn{3}{|l|}{ Pendidikan ibu } \\
\hline Tinggi & 113 & 50.9 \\
\hline Rendah & 109 & 49.1 \\
\hline \multicolumn{3}{|l|}{ Pendidikan suami } \\
\hline Tinggi & 121 & 54.5 \\
\hline Rendah & 101 & 45.5 \\
\hline \multicolumn{3}{|l|}{ Pekerjaan ibu } \\
\hline Tidak bekerja & 196 & 88.3 \\
\hline Bekerja & 26 & 11.7 \\
\hline \multicolumn{3}{|l|}{ Pekerjaan suami } \\
\hline Bekerja & 220 & 99.1 \\
\hline Tidak bekerja & 2 & 0.9 \\
\hline \multicolumn{3}{|l|}{ Paritas } \\
\hline Minimal 1 anak & 71 & 32.0 \\
\hline Minimal 2 anak & 151 & 68.0 \\
\hline \multicolumn{3}{|c|}{ Tingkat kesejahteraan keluarga } \\
\hline$<$ Rp. 2.294 .000 & 137 & 61.7 \\
\hline$\geq$ Rp. 2.294 .000 & 85 & 38.3 \\
\hline \multicolumn{3}{|l|}{ Tempat bersalin } \\
\hline Faskes & 212 & 95.5 \\
\hline Non-faskes & 10 & 4.5 \\
\hline \multicolumn{3}{|l|}{ Pemberian ASI Eksklusif } \\
\hline Ya & 23 & 10.4 \\
\hline Tidak & 199 & 89.6 \\
\hline
\end{tabular}




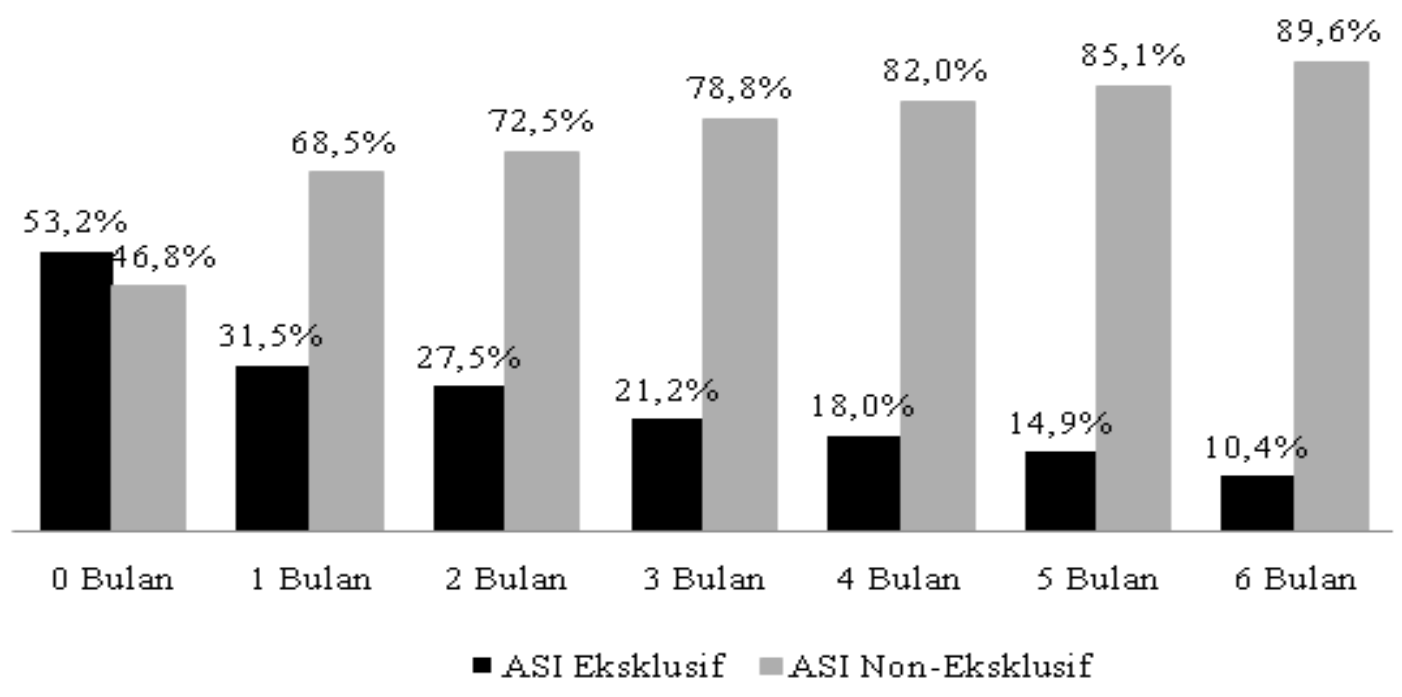

\section{Gambar 1. Pola Pemberian ASI Eksklusif dan Non-Eksklusif Pada Bayi Usia 6 Bulan}

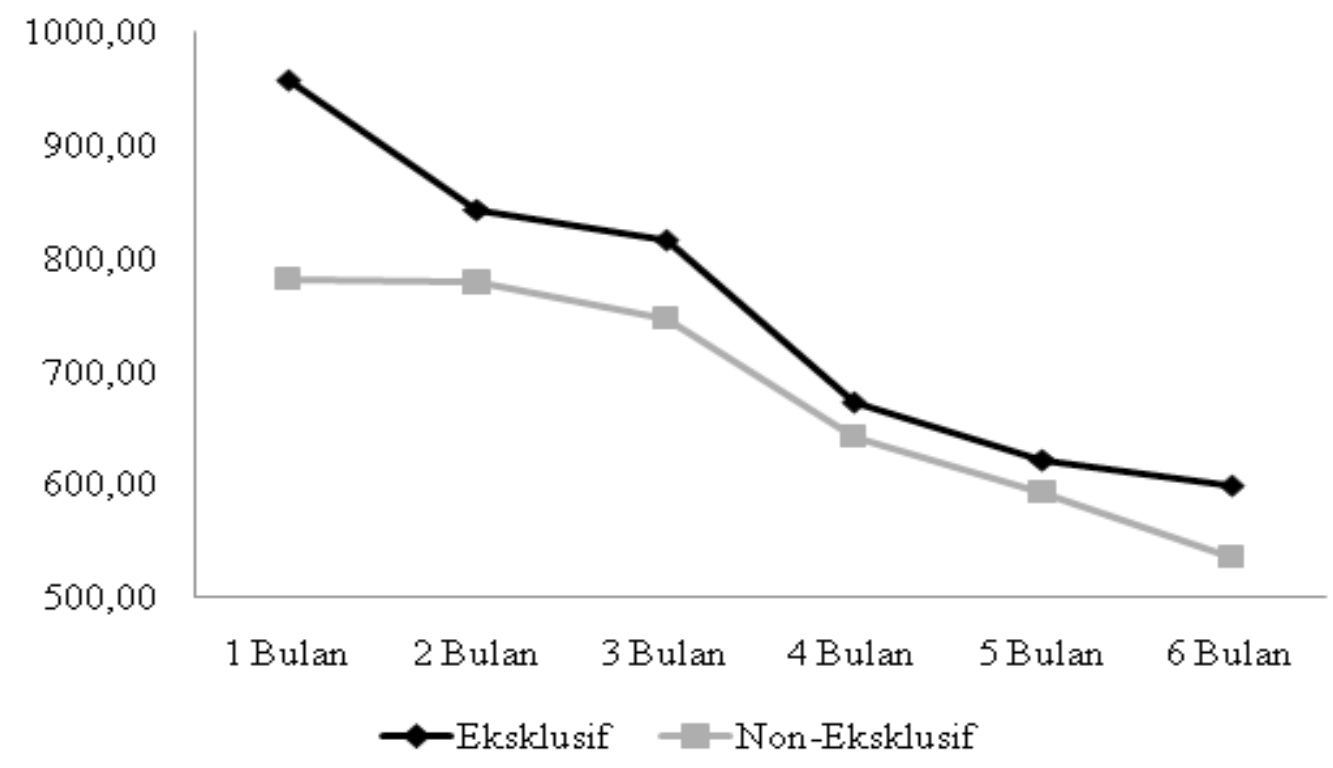

\section{Gambar 2. Pertambahan Rata-rata Berat Badan Bayi Berdasarkan Status Menyusui Eksklusif}

9\% dibandingkan suami berpendidikan rendah. Sebanyak $88,3 \%$ ibu tidak bekerja dengan tingkat kesejahteraan keluarga rendah $(<\mathrm{Rp}$. 2.294.000) sebanyak $61,7 \%$. Ibu yang memiliki anak minimal 2 anak lebih banyak 36\% dibandingkan ibu dengan minimal 1 anak dan hanya 4,5\% ibu yang melahirkan di fasilitas non kesehatan (rumah). Prevalensi pemberian ASI eksklusif di Kecamatan Seberang Ulu I Kota Palembang hanya 10,4\% (Tabel 1). Sebanyak 53,2\% bayi mendapatkan ASI dan sebanyak $46,8 \%$ bayi yang tidak mendapatkan ASI sesaat setelah dilahirkan. Proporsi ini mengalami penurunan dengan cepat yaitu hanya sebanyak $31,5 \%$ bayi yang mendapatkan ASI saja pada 1 bulan, 27,5\% bayi yang mendapatkan ASI saja pada 2 bulan, $21,2 \%$ bayi yang mendapatkan ASI saja pada 3 bulan, $18,0 \%$ bayi yang mendapatkan ASI saja pada 4 bulan, 14,9\% bayi yang mendapatkan ASI saja pada 5 bulan dan hanya 10,4\% bayi mendapatkan ASI eksklusif sampai usia 6 


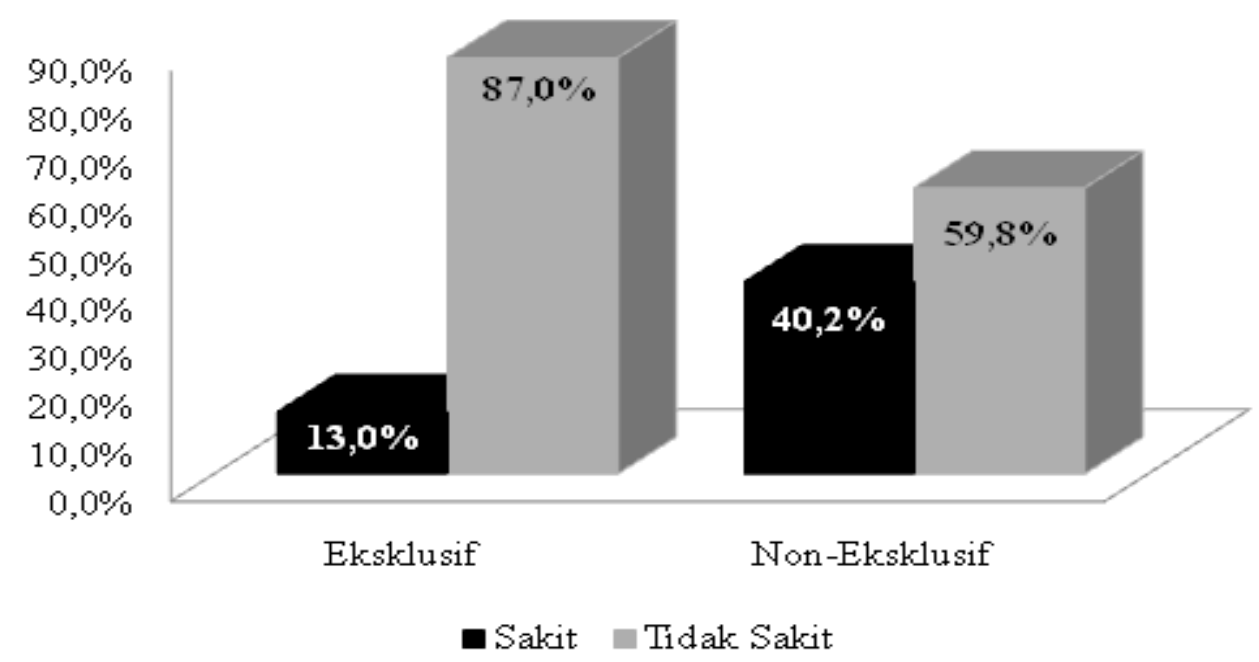

Gambar 3. Pola Morbiditas pada Bayi Berdasarkan Status Menyusui Eksklusif

Tabel 2. Perbandingan Pertambahan Rata-rata Berat Badan Bayi Berdasarkan Status Menyusui Eksklusif

\begin{tabular}{lcccccc}
\hline $\begin{array}{c}\text { Sampai usia 6 } \\
\text { bulan }\end{array}$ & ASI Ekslusif & $\begin{array}{c}\text { ASI Non- } \\
\text { eksklusif }\end{array}$ & $\begin{array}{c}\text { Mean } \\
\text { Difference }\end{array}$ & $\begin{array}{c}\text { Standard } \\
\text { Error }\end{array}$ & 95\% CI MD & p \\
\hline $\begin{array}{l}\text { Jumlah bayi } \\
\begin{array}{l}\text { Pertambahan } \\
\text { berat badan }\end{array}\end{array}$ & $\begin{array}{c}23 \\
4.514,8 \pm 1.095,4\end{array}$ & $\begin{array}{c}199 \\
4.081,1 \pm 915,4\end{array}$ & 433,6 & 205,9 & $27,8-839,4$ & 0,036 \\
\hline
\end{tabular}

bulan (Gambar 1). Berbeda halnya dengan prevalensi pemberian ASI eksklusif yang semakin menurun, rata-rata pertambahan berat badan pada bayi yang menyusui eksklusif sampai usia 6 bulan lebih tinggi dibandingkan dengan rata-rata pertambahan berat badan pada bayi yang menyusui non-eksklusif pada usia yang sama pada setiap bulannya (Gambar 2).

Hasil analisis bivariabel menggunakan uji T-Independen diperoleh rata-rata pertambahan berat badan bayi pada bayi yang menyusui eksklusif lebih tinggi 433,63 gram dibandingkan pada bayi yang menyusui non-eksklusif selama 6 bulan $(95 \% \mathrm{CI}=27,81-839,45 ; \mathrm{p}=0,036)$. Pada populasi umum, peneliti yakin $95 \%$ bahwa ratarata pertambahan berat badan pada bayi yang menyusui eksklusif dan non-eksklusif berada dalam rentang interval 27,81 gram sampai dengan 839,45 gram (Tabel 2). Selain itu, kejadian sakit (morbiditas) dialami oleh bayi pada usia 6 bulan yang menyusui eksklusif $(13,0 \%)$ dan sebanyak $40,2 \%$ pada bayi yang diberikan ASI non- eksklusif (Gambar 3). Pola pemberian ASI eksklusif berdasarkan karakteristik sosial demografi dengan menggunakan uji chi-square menunjukkan bahwa hanya pendidikan suami yang memiliki efek signifikan secara statistik terhadap pola pemberian ASI eksklusif (PR:5,56; 95\% CI: 1,7018,19; $\mathrm{p}=0,002)$, sedangkan umur ibu melahirkan, pendidikan ibu, pekerjaan ibu, tingkat kesejahteraan keluarga, paritas dan tempat bersalin tidak memiliki hubungan pada pola pemberian ASI eksklusif $(p>0,05)$ (Tabel 3).

\section{PEMBAHASAN}

Berat badan merupakan salah satu indikator guna memantau pertumbuhan (growth) pada bayi, khususnya dalam 6 bulan pertama kehidupan. Hasil penelitian menjelaskan bahwa rata-rata berat badan bayi bertambah sebesar $687,7 \mathrm{gram} /$ bulan dan rata-rata berat badan pada usia 5 bulan (6.686,5 gram), 6 bulan (7.228,8 gram) sehingga rata-rata berat badan pada usia 5-6 bulan bertambah 2 kali lipat dibandingkan rata-rata berat badan 
Tabel 3. Pola Pemberian ASI Eksklusif Berdasarkan Karakteristik Sosial Demografi Ibu

\begin{tabular}{|c|c|c|c|c|c|c|}
\hline \multirow{3}{*}{ Variabel } & \multicolumn{4}{|c|}{ Pemberian ASI Eksklusif } & \multirow{3}{*}{ PR (95\% CI) } & \multirow{3}{*}{$\mathbf{p}$} \\
\hline & \multicolumn{2}{|c|}{ Ya } & \multicolumn{2}{|c|}{ Tidak } & & \\
\hline & $\mathbf{n}$ & $\%$ & $\mathbf{n}$ & $\%$ & & \\
\hline \multicolumn{7}{|c|}{ Umur ibu melahirkan (tahun) } \\
\hline $20-35$ & 20 & 11.30 & 157 & 88.7 & $1,69(0,53-5,45)$ & 0,58 \\
\hline$<20$ dan $>35$ & 3 & 6.7 & 42 & 93.3 & Reference & \\
\hline \multicolumn{7}{|l|}{ Pendidikan ibu } \\
\hline Tinggi & 16 & 14.2 & 97 & 85.8 & $2,20(0,94-5,15)$ & 0,09 \\
\hline Rendah & 7 & 6.4 & 102 & 93.6 & Reference & \\
\hline \multicolumn{7}{|l|}{ Pendidikan suami } \\
\hline Tinggi & 20 & 16.5 & 101 & 83.5 & $5,56(1,70-18,19)$ & 0,002 \\
\hline Rendah & 3 & 3.0 & 98 & 97.0 & Reference & \\
\hline \multicolumn{7}{|l|}{ Pekerjaan ibu } \\
\hline Tidak bekerja & 20 & 10.2 & 176 & 89.8 & $0,84(0,28-2,77)$ & 0,74 \\
\hline Bekerja & 3 & 11.5 & 23 & 88.5 & Reference & \\
\hline \multicolumn{7}{|l|}{ Pekerjaan suami } \\
\hline Bekerja & 0 & 0.0 & 2 & 100.0 & - & 0,100 \\
\hline Tidak bekerja & 23 & 10.5 & 197 & 89.5 & Reference & \\
\hline \multicolumn{7}{|l|}{ Paritas } \\
\hline Minimal 1 anak & 6 & 8.5 & 65 & 91.5 & $0,75(0,31-1,82)$ & 0,69 \\
\hline Minimal 2 anak & 17 & 11.3 & 134 & 88.7 & Reference & \\
\hline \multicolumn{7}{|c|}{ Tingkat kesejahteraan keluarga } \\
\hline < Rp. 2.294 .000 & 11 & 8.0 & 126 & 92.0 & $2,20(0,94-5,15)$ & 0,13 \\
\hline$\geq$ Rp. 2.294 .000 & 12 & 14.1 & 73 & 85.9 & Reference & \\
\hline \multicolumn{7}{|l|}{ Tempat bersalin } \\
\hline Faskes & 22 & 10.4 & 190 & 89.6 & $1,04(0,16-6,95)$ & 1,000 \\
\hline Non-faskes & 1 & 10.0 & 9 & 90.0 & Reference & \\
\hline
\end{tabular}

pada saat lahir (3.102,7 gram). Selain itu, rata-rata pertambahan berat badan pada 3 bulan pertama kelahiran sebesar 780,2 gram dan pada 3 bulan selanjutnya bertambah sebesar 595,2 gram. Hasil penelitian ini sejalan dengan teori yang menyatakan bahwa berat badan bayi bertambah sebesar 682 gram/bulan pada 6 bulan pertama kelahiran dan akan bertambah 2 kali lipat ketika bayi berusia $>4$ bulan. Rata-rata penambahan berat badan bayi sebesar $0,7-0,75 \mathrm{~kg} /$ bulan pada 3 bulan pertama dan sebesar $0,5-0,6 \mathrm{~kg} /$ bulan pada 3 bulan selanjutnya. ${ }^{11}$

Salah satu faktor yang mempengaruhi peningkatan atau penurunan berat badan bayi adalah ASI. ASI merupakan makanan utama kaya nutrisi yang hanya dapat dicerna bayi dikarenakan sistem pencernaaan bayi belum mampu berfungsi dengan sempurna sehingga bayi belum mampu mencerna makanan selain ASI sebelum mencapai usia 6 bulan. ${ }^{12}$ Pemberian ASI eksklusif mengalami penurunan selama 6 bulan kehidupan bayi. Hasil penelitian ini didukung hasil penelitian sebelumnya bahwa terjadi penurunan prevalensi pemberian ASI eksklusif selama 6 bulan kehidupan bayi di Nigeria, Gujarat dan Malawi. ${ }^{5,8,13,14}$ Selain itu, bayi yang menyusui eksklusif mempunyai ratarata pertambahan berat badan yang lebih tinggi dibandingkan bayi yang menyusui non-eksklusif. Rata-rata berat badan bayi yang menyusui eksklusif lebih tinggi 176 gram pada bulan pertama, 64,6 gram pada bulan kedua, 69,65 gram pada bulan ketiga, 30,70 gram pada bulan keempat, 27,77 gram pada bulan kelima dan 64,32 gram pada bulan keenam bila dibandingkan dengan bayi yang menyusui non-eksklusif dan hasil penelitian ini signifikan secara statistik $(p<0,05)$. Hasil penelitian ini didukung hasil penelitian sebelumnya bahwa rata-rata berat bayi yang menyusui eksklusif lebih tinggi dibandingkan bayi yang menyusui non-eksklusif $(\mathrm{p}<0,05) .{ }^{5,8,14}$ Ara et al., menyatakan bahwa bayi yang mendapatkan ASI non-eksklusif memiliki kemungkinan 4,3 kali 
untuk mengalami gangguan pertumbuhan (berat badan perumur) dibandingkan bayiyang mendapatkan ASI eksklusif $(95 \% \mathrm{CI}=1,7-11,1 ; \mathrm{p}=0,001) .{ }^{15}$ Sementara itu, studi Kurniawan et al., melaporkan bahwa bayi yang diberikan ASI eksklusif lebih banyak mengalami pertambahan berat badan yang normal dan cepat dibandingkan bayi yang diberikan susu formula, MP-ASI dan keduanya. ${ }^{16}$ Selain berpengaruh terhadap berat badan bayi, pemberian ASI eksklusif juga mempengaruhi panjang badan bayi. Devriany et al., dan Kuchenbecker et al., menyimpulkan bahwa bayi yang menyusui eksklusif mempunyai rata-rata panjang badan yang lebih tinggi dibandingkan bayi yang menyusui non-eksklusif $(p<0,05) .^{12,14}$

Salah satu kandungan gizi dalam ASI yaitu karbohidrat dalam bentuk laktosa, akan memiliki jumlah yang dinamis sesuai dengan kebutuhan nutrisi selama proses pertumbuhan dan perkembangan bayi yang salah satunya adalah pertambahan berat badan. Pertambahan berat pada bayi yang menyusui eksklusif tidak menyebabkan bayi mengalami kemungkinan kelebihan berat badan (overweight) dan obesitas serta berat badan yang diperoleh selama 6 bulan pertama kehidupan bayi merupakan manifes bagi berat badan pada periode selanjutnya. Studi Nur dan Marissa tahun 2014 menyimpulkan bahwa bayi yang menyusui eksklusif memiliki berat badan normal dibandingkan bayi yang menyusui non-eksklusif yang cenderung mempunyai berat badan berlebih pada usia enam bulan. ${ }^{17}$ Studi Abdiana juga menyimpulkan bahwa anak dengan riwayat pemberian ASI eksklusif memiliki kemungkinan yang lebih rendah untuk mengalami kelebihan berat badan dibandingkan dengan anak tanpa riwayat pemberian ASI eksklusif (OR: 0,37; 95\% CI: $0,19-0,67 ; p=0,001) .{ }^{18}$

Selain karbohidrat, jumlah protein dalam ASI juga jauh lebih rendah bila dibandingkan dengan makanan pengganti ASI lainnya. Namun, jumlah protein ini sangat cocok bagi bayi dikarenakan hampir seluruh protein yang terdapat dalam ASI dapat terserap dengan sempurna oleh sistem pencernaan bayi sehingga bayi lebih terlindungi dari penyakit infeksi seperti gangguan percernaan (diare). Proporsi kejadian sakit (morbiditas) pada usia bayi 6 bulan yang menyusui non-eksklusif lebih tinggi dibandingkan bayi yang menyusui eksklusif. Diantara bayi yang menyusui noneksklusif ini sebanyak 47,5\% mengalami demam, $35,0 \%$ mengalami batuk dan flu, $12,5 \%$ mengalami diare dan sebanyak 5,0\% mengalami alergi, campak dan Infeksi Saluran Pernapasan Akut (ISPA). Hasil penelitian ini didukung oleh hasil penelitian sebelumnya yang menyatakan bahwa balita yang menyusui non-eksklusif berisiko 1,4 kali mengalami penyakit infeksi dibandingkan balita yang menyusui eksklusif $(95 \% \mathrm{CI}$ : 1,24 1,64). ${ }^{17}$ Selain itu, Chauhan et al., juga menyimpulkan bahwa bayi yang menyusui eksklusif berkemungkinan lebih rendah untuk mengalami sakit dalam kurun waktu 6 bulan dibandingkan bayi yang menyusui non-eksklusif. ${ }^{8} \mathrm{Hal}$ ini disebabkan oleh karena ASI mengandung zat kekebalan tubuh yang alami sehingga tidak berdampak apapun terhadap kesehatan bayi dan kandungan ASI baik untuk kesehatan saluran cerna bayi. Oligosakarida yang merupakan faktor bifidus pada ASI mampu merangsang pertumbuhan dan aktivitas bakteri Bifidobacteria dalam saluran cerna. ${ }^{17}$ Selain itu, didalam ASI juga terkandung Imunoglobulin, laktoferin dan lisozim (muramidase). SIgA (secretory immunoglobulin A) yang terkandung dalam ASI berfungsi sebagai antisepticintestinal paint yang melindungi permukaan usus bayi terhadap invasi mikroorganisme patogen (termasuk E.coli) dan protein asing. Imunoglobulin tidak terdapat pada kandungan susu formula, madu, air tajin bahkan air putih. Bayi yang diberi makanan tambahan ASI berupa cairan tidak akan mendapatkan imunoglobulin dari intake makanannya. Selain itu, penggunaan botol susu juga akan meningkatkan risiko sakit bayi yang disebabkan oleh kekuranghigienisan dalam proses pencucian botol, penyimpanan botol dan penggunaan botol susu. ${ }^{19}$ Sebagai tambahan, penggunaan botol susu dapat pula mengganggu pematangan fungsi oral pada bayi yang ditandai dengan terjadinya peningkatan risiko pernapasan melalui mulut, disfungsi pengunyahan, kesulitan artikulasi katakata, peningkatan risiko infeksi pernapasan dan penurunan fungsi pendengaran. ${ }^{20}$ Sehingga bayi yang menyususi non-eksklusif berisiko mengalami penyakit infeksi dan terganggu proses perkembangannya dibandingkan bayi yang menyusui eksklusif.

Selain itu, pendidikan suami merupakan 
variabel yang berkaitan dengan menyusui eksklusif. Prevalensi menyusui eksklusif lebih banyak pada ibu yang memiliki suami berpendidikan tinggi (SMA ke atas) dibandingkan suami berpendidikan rendah (SMP ke bawah). Hasil penelitian ini sejalan dengan penelitian Ratnasari et al., tahun 2017 yang menyimpulkan bahwa ibu dengan suami berpendidikan tinggi memiliki kemungkinan 2,68 kali lebih tinggi untuk memberikan ASI eksklusif dibandingkan ibu dengan suami berpendidikan rendah (95\% CI: $1,15-6,25 ; p=0,02){ }^{21}$

Penelitian Ananta et al., melaporkan bahwa pendidikan suami berhubungan dengan menyusui eksklusif di Indonesia $(p=0,006) .{ }^{22}$ Mekuria dan Edris juga mendukung hasil penelitian ini dengan melaporkan bahwa ibu dengan suami berpendidikan berkemungkinan 1,83 kali lebih tinggi untuk memberikan ASI eksklusif kepada bayinya dibandingkan ibu dengan suami tidak berpendidikan (95\% CI: 1,10-3,04) ${ }^{23}$ Earsido et al., tahun 2017 menyatakan pula bahwa ibu yang memiliki suami yang tidak mampu membaca dan menulis (buta huruf) memiliki kemungkinan 0,34 kali lebih rendah untuk menyusui eksklusif dibandingkan ibu yang memiliki suami berpendidikan menengah keatas $(95 \% \mathrm{CI}: 0,12-0,95 ; \mathrm{p}=0,039) .{ }^{24}$ Namun, hasil penelitian ini tidak sejalan dengan penelitian Thaha et al., dan Hossain et al., yang melaporkan bahwa tingkat pendidikan suami tidak berhubungan dengan pemberian ASI eksklusif $(p>0,05) .^{25,26}$

Pendidikan suami dapat menjadi suatu langkah besar menuju keberhasilan menyusui. Suami yang memiliki tingkat pendidikan rendah relatif sulit dalam menerima sesuatu hal yang baru dan sebaliknya suami yang memiliki pendidikan tinggi akan lebih mudah menerima hal yang baru dan cenderung lebih terbuka (open-minded). Penelitian Nchimunya et al., menyatakan bahwa semakin tinggi pendidikan suami, semakin tinggi pula prevalensi suami memiliki pengetahuan baik mengenai ASI eksklusif. ${ }^{27}$ Studi Lupiana juga menunjukkan bahwa pengetahuan suami berhubungan dengan menyusui eksklusif $(\mathrm{p}=0,02){ }^{28}$ Pengetahuan tentang masalah-masalah yang berhubungan dengan pemberian ASI merupakan hal yang harus dimiliki suami untuk dapat mengambil bagian dalam proses pembuatan keputusan mengenai pola pemberian makan bagi bayi dan membantu ibu dalam mendapat-kan informasi tentang menyusui sehingga mampu memberikan dorongan dan motivasi bagi ibu dalam menyusui eksklusif. Studi Fitri et al., dan Atika et al., menyimpulkan bahwa dukungan suami berhubungan dengan menyusui eksklusif pada ibu $(\mathrm{p}<0,05) \cdot{ }^{29,30}$ Arifah et al., juga menyimpulkan bahwa dukungan suami berhubungan dengan pemberian ASI eksklusif ( $p<0,001$ ) dengan sebanyak $76,2 \%$ peran suami dalam keterlibatan pengasuhan anak, keterlibatan dalam proses persalinan $(40,0 \%)$, keterlibatan dalam pengambilan keputusan $(23,8 \%)$ dan pencarian informasi $(16,2 \%) \cdot{ }^{31}$ Lima peran utama suami dalam mendukung keberhasilan pemberian ASI oleh ibu antara lain pengetahuan, sikap positif, keterlibatan suami dalam pengambilan keputusan, dukungan praktis dan emosional. Sikap dan dukungan positif atau negatif suami terhadap menyusui dapat mempengaruhi perilaku menyusui ibu. ${ }^{2}$

\section{KESIMPULAN DAN SARAN}

Proporsi bayi yang mendapatkan ASI eksklusif dalam penelitian ini semakin berkurang seiring dengan bertambahnya usia bayi dalam 6 bulan pertama. Bayi yang menyusui eksklusif mempunyai rata-rata pertambahan berat badan yang lebih tinggi dibandingkan bayi yang menyusui non-eksklusif.Sebaliknya, prevalensi kejadian sakit (morbiditas) pada bayi yang menyusui eksklusif lebih rendah bila dibandingkan bayi yang menyusui non-eksklusif. Pendidikan suami berhubungan dengan praktik pemberian ASI eksklusif $(p=0,002)$, sedangkan variabel lain tidak berhubungan dengan praktik pemberian ASI eksklusif di Kecamatan Seberang Ulu I Kota Palembang.

Disarankan bagi ibu selalu melibatkan suami dalam proses menyusui eksklusif yang tidak hanya dilakukan setelah bayi dilahirkan (postnatal), tetapi sebelum bayi dilahirkan (prenatal) seperti dalam proses pencarian informasi mengenai menyusui, keterlibatan suami dalam pengambilan keputusan terkait dengan pola pemberian makan pada anak, keterlibatan dalam proses persalinan dan pengasuhan anak. Dukungan suami dapat memberikan motivasi bagi ibu untuk mencapai keberhasilan menyusui eksklusif dan mengatasi berbagai masalah dalam proses menyusui selama 6 bulan kehidupan bayi. Selain itu, penelitian lebih lanjut perlu dikembangkan untuk menganalisis berbagai 
faktor yang berkaitan dengan keterlibatan atau dukungan suami dalam menyusui eksklusif.

\section{UCAPAN TERIMA KASIH}

Penelitian ini menerima dana Hibah Penelitian Sains, Teknologi dan Seni (SATEKS) dari Lembaga Penelitian dan Pengabdian Kepada Masyarakat (LP2M) Universitas Sriwijaya. Peneliti menyampaikan terima kasih kepada para asisten peneliti dari Fakultas Kesehatan Masyarakat (FKM) Universitas Sriwijaya dan responden yang telah bersedia membantu terlaksananya kegiatan penelitian ini.

\section{DAFTAR PUSTAKA}

1. WHO/UNICEF. Global Nutrition Targets 2025: Breastfeeding Policy Brief(WHO/ NMH/NHD/14.7). Geneva: World Health Organization; 2014.

2. Kemenkes RI. Hasil Pemantauan Status Gizi (PSG) Tahun 2017. Jakarta: Kementerian Kesehatan RI; 2018.

3. Kemenkes RI. Rencana Strategis Kementerian Kesehatan Tahun 2015-2019. Jakarta: Kementerian Kesehatan RI; 2015.

4. Qulub ST. Pembentukan Kualitas Pada 1000 Hari Pertama Kehidupan Perspektif Hukum Islam. Al-Jinayah Jurnal Hukum Pidana Islam. 2016;2(2):472-96.

5. Ukegbu P, Uwaegbute A. Growth Pattern of Exclusively and Non-Exclusively Breastfed Infants in Umuahia Urban, Nigeria. Journal of Community Nutrition \& Health. 2013;2(1):68-75.

6. Kumar Singh A, Kumar Singh R, Sah RP, Ahmad E, Alam Ansari A, Mansuri Islam M. Comparison of Growth Pattern in Neonates on Breast Feed Versus Formula Feed. Med Phoenix. 2017;2(1):18-23.

7. Küpers LK, L'Abée C, Bocca G, Stolk RP, Sauer PJJ, Corpeleijn E. Determinants of Weight Gain during the First Two Years of Life-The GECKO Drenthe Birth Cohort. PLoS One. 2015;10(7):1-15.

8. Chauhan M, Mehta D, Koria B, Patel H, Singh M. Assessment of Weight Gain Pattern of Exclusively Breastfed and Nonexclusively Breastfed Infants in Bhavnagar City, Gujarat. Int J Med Sci Public Health. 2016;5(1):64-8.
9. Goran MI, Martin AA, Alderete TL, Fujiwara $\mathrm{H}$, Fields DA. Fructose in Breast Milk is Positively Associated with Infant Body Composition at 6 Months of Age. Nutrients. 2017 Feb 16;9(2):146.

10. Pemerintah Kota Palembang Dinas Kesehatan. Profil Kesehatan Tahun 2016. Palembang: Dinas Kesehatan Kota Palembang; 2017.

11. Cahyaningsih DS. Pertumbuhan Perkembangan Anak \& Remaja. Jakarta: TIM; 2011.

12. Devriany A, Wardani Z, Yunihar. Perbedaan Status Pemberian ASI Eksklusif terhadap Perubahan Panjang Badan Bayi Neonatus. Jurnal MKMI. 2018;14(1):44-51.

13. Ebirim C, Dozie UW, Akor W, Dozie IJ, Ashiegbu OA. Exclusive Breastfeeding Practice and Associated Maternal Socio-Demographic Factors among Mothers Attending Imo State Specialist Hospital, Owerri, South-Eastern Nigeria. Archives of Community Medicine and Public Health. 2016;2(1):27-31.

14. Kuchenbecker J, Jordan I, Reinbott A, Herrmann J, Jeremias T, Kennedy G, et al. Exclusive breastfeeding and Its Effect on Growth of Malawian Infants: Results From A Cross Sectional Study. Paediatrics International Child Health. 2015;35(1):14-23.

15. Ara MA, Surdaryati E, Lubis Z. Infant's Growth and Development at the Age of 6-12 Months Based on Breastfeeding. International Journal Public Health Sciences (IJPHS). 2018;7(2):120-9.

16. Kurniawan J, Anggraini A, Julia M. Infant Feeding Practice on Growth Velocity in 4-6 Month-olds. Paediatrica Indonesiana. 2018;58(1):36-41.

17. Nur A, Marissa N. Riwayat Pemberian Air Susu Ibu dengan Penyakit Infeksi pada Balita. Kesmas, Jurnal Kesehatan Masyarakat Nasional. 2014;9(2):144-9.

18. Abdiana. Hubungan Durasi Pemberian ASI dengan Kejadian Berat Badan Lebih pada Anak Taman Kanak-kanak. MKA. 2014;37(1):50-7.

19. Putri R, Illahi SA. Hubungan Pola Menyusui dengan Frekuensi Kejadian Sakit pada Bayi. Journalof Issues in Midwifery. 2017;1(1):118.

20. Brahm P, Valdes V. Benefit of Breastfeeding and Risks Associated with not Breastfeeding. 
Revista Chilena de Pediatria. 2017;88(1):1521.

21. Ratnasari D, Paramashanti BA, Hadi H, MNurs AYN, Astiti D, Nurhayati E. Family Support and Exclusive Breastfeeding among Yogyakarta Mothers in Employment. Asia Pacific Journal of Clinical Nutrition. 2017;26(S1):s31-5.

22. Ananta Y, Gandaputra E, Waiman E, Gusti Ayu Nyoman Partiwi I, Marzuki N, Yohmi $\mathrm{E}$, et al. Exclusive Breastfeeding Rate and Factors Associated with Infant Feeding Practices in Indonesia. Paediatrica Indonesiana. 2016;56(1):24-31.

23. Mekuria G, Edris M. Exclusive Breastfeeding and Associated Factors Among Mothers in Debre Markos, Northwest Ethiopia: A Cross Sectional Study. International Breastfeeding Journal. 2015;10(1):1-7.

24. Earsido A, Abebe W, Dereje N. Prevalence and Determinants of Exclusive Breastfeeding Practices among Infants in Hossana Town, Southern Ethiopia: A Community Based Cross-Sectional Study. EC Gynaecol. 2017;4(3):69-79.

25. Thaha ILM, Razak R, Ansariadi. Determinan Pemberian ASI Eksklusif oleh Ibu Multipara di Kabupaten Jeneponto. Jurnal MKMI. 2015;11(4):247-52.

26. Hossain M, Islam A, Kamarul T, Hossain G.
Exclusive Breastfeeding Practice during First Six Months of an Infant's Life in Bangladesh: ACountry Based Cross-Sectional Study. BMC Pediatrics. 2018;18(1):93.

27. Nchimunya C, Halwiindi H, Allan M, Alice H, Chimfwembe K. Factors Affecting the Adoption of Exclusive Breastfeeding by Mothers in Chelstone, Lusaka. International Invention Journal of Medicine and Medical Sciences. 2015;2(5):73-9.

28. Lupiana M. Hubungan Pengetahuan dan Sikap Suami terhadap Menyusui Eksklusif di Wilayah Kerja Puskesmas Kupang Kota Kecamatan Teluk Betung Utara Kota Bandar Lampung. Jurnal Kesehatan Metro Sai Wawai. 2015;VIII(1):25-31.

29. Fitri N, Lestari Y, Evareny L. The Relation Between Husband Support with Exclusive Breastfeeding in Baby Age 6-12 Months in Air Dingin Health Center. Journal of Midwifery. 2017;2(2):74-81.

30. Atika Z, Salimo H, Dewi YLR. Multilevel Analysis on the Determinants of Exclusive Breastfeeding at Gunung Anyar Community Health Center, Surabaya, Indonesia. Journal of Maternal and Child Health. 2018;3(3):176-83.

31. Arifah I, Rahayuning D, Rahfiludin MZ. Father's Role on the Exclusive Breastfeeding Practice. KESMAS. 2014;8(2):83-92. 